Journal of American Studies, 55 (202 I), 3, 620-656

(C) Cambridge University Press and British Association for American Studies 2020. This is an Open Access article, distributed under the terms of the Creative Commons Attribution licence (http://creativecommons.org/licenses/by/4.0/), which permits unrestricted re-use, distribution, and reproduction in any medium, provided the original work is properly cited.

doi:10.1017/S0021875820000699 First published online 3 July 2020

\title{
Lessons in Graphic Nonfiction: John Lewis, Andrew Aydin, and Nate Powell's March Trilogy and Civil Rights Pedagogy
}

\section{DANIEL STEIN}

Playing into the master narrative of the US civil rights movement, John Lewis, Andrew Aydin, and Nate Powell's March trilogy negotiates not only the movement's tactics and achievements, but also its initial mediation through photography and television and its ongoing remediation. Taking the memoir's urge to teach as a starting point, this article assesses its didactic impulses and implications, combining a historiographic approach with an assessment of the narrative's visual construction. The article highlights the trilogy's potentials and shortcomings as an intervention into civil rights memory and outlines a metacritical pedagogy through which March can become potent classroom material.

Writing in the International Journal of Comic Art, Dartmouth professor Michael A. Chaney opens a recent essay on the first book of John Lewis, Andrew Aydin, and Nate Powell's best-selling three-part graphic memoir March with reflections on his students' reaction to its depiction of the American civil rights movement: ${ }^{\mathrm{I}}$

Monumental though Lewis and his text may have been ... neither he nor his memoir could satisfactorily rebuke the injustices associated with what seemed ... a daily report of chilling police shootings. Many demoralized students wanted a graphic text with more bite ... They wanted a text in aggressive proportion to the fatal onslaught of state-sanctioned brutalities perpetrated against innocent, often poor black subjects. Contrary to the unsteady consensus of the moment, March was perceived to be eking out a message of ultimate trust in the state and state processes ... [S] everal of my students found March's narrative framing of political optimism staggeringly

English Department, Universität Siegen Fakultät I Philosophische Fakultät. Email: stein@ anglistik.uni-siegen.de.

${ }^{1}$ John Lewis, Andrew Aydin and Nate Powell, March: Book One (Marietta: Top Shelf, 20 13 ); Lewis, Aydin and Powell, March: Book Two (Marietta: Top Shelf, 2015); Lewis, Aydin and Powell, March: Book Three (Marietta: Top Shelf, 2016). 
inappropriate to the Uzi spray of racism from media outlets. Beyond harboring an agenda of black political conformity, March smacked of chauvinisms both political and otherwise, tying the graphic memoir to a type of black resistance widely thought to be ineffectual in our contemporary moment. ${ }^{2}$

Gauging the students' reaction as dissatisfaction with "the text's political failings and historical fetishes,"3 Chaney recognizes a yearning for more confrontational narratives and more aggressive political options than offered by Lewis's philosophy of "good trouble,"4 the dignified forms of nonviolent protest that defined much of the civil rights movement. At a time when the killings of black Americans by US police dominated the news and when the Black Lives Matter movement was gaining traction, March celebrated nonviolent forms of resistance, expressed a continuing belief in the American political system, and turned to the lessons of the past instead of addressing the problems of the present.

When the first book of the trilogy appeared in 2013, however, Barack Obama was still President and Michael Brown, Miriam Carey, Eric Garner, Mya Hall, John Crawford, Tamir Rice, and Freddie Gray were still alive. There had been a racially motivated backlash against Obama from the very beginning of his presidency, and police killings of African Americans did not just start in the 20 Ios. Nonetheless, black civil rights legend and US Congressman John Lewis, his aide Andrew Aydin, and graphic artist Nate Powell found sufficient inspiration in Obama's election to present Lewis's lifelong struggle against racism and discrimination as the prehistory to, and precondition of, the first black President by suffusing the narrative with images of Obama's first inauguration. Lewis and his collaborators celebrate what the books pitch as the long-term impact of the civil rights movement, especially of the Selma, Alabama campaign, in which Lewis was involved as a member of the Student Nonviolent Coordinating Committee (SNCC). In Selma's Bloody Sunday: Protest, Voting Rights, and the Struggle for Racial Equality, Robert A. Pratt affirms that the "election of the first African-American president in 2008 reflected the apex of black political power," which supports March's presentation of the civil rights movement as an eventual success story. Yet Pratt also sees a paradox according to which Obama's election "revealed ... an increase in black electoral participation and a rapidly changing political landscape [that] prompted white conservatives to resort to a new

${ }^{2}$ Michael A. Chaney, "Misreading with the President: Re-reading the Covers of John Lewis's March," in Daniel Stein, Lukas Etter and Michael A. Chaney, eds., Transnational Graphic Narratives, special symposium, International Journal of Comic Art, 20, I (2018), 25-42, 25. 3 Ibid., 25.

4 The Late Show with Stephen Colbert, "Congressman John Lewis: 'Get in Trouble. Good Trouble," I Sept. 2016, at www.youtube.com/watch?v=6ATwisIrtfg. 
campaign of voter restrictions." His conclusion "that the lessons of Selma have yet to be learned" complicates the historical trajectory of the March books. ${ }^{5}$

Writing more than a decade before Pratt and around the same time Obama prepared his bid for the presidency as a speaker at the Democratic National Convention in 2004, Jacquelyn Dowd Hall had already maintained that rather than unfold along a straight line, the civil rights movement developed from a "dialectic between the movement and the so-called backlash against it." This backlash "arose in tandem with the civil rights offensive in the aftermath of World War II," and it did not end in the I970s, as common movement history alleges, but "culminated under the aegis of the New Right." 6 Among the March books' most prominent political failings may thus be its underestimation of the backlash against the long-term advancements of the civil rights movement, a backlash that had gathered steam during Obama's "eight years in power," 7 broke out into the open with election of Donald J. Trump, and undermines the progressive optimism of the trilogy.

Scholarship on March has only begun to account for its political thrust. Those who have engaged with this graphic narrative have noted its entrenchment in what Hall defines as the "dominant" or "master" narrative of the movement, the "confining of the civil rights struggle to the South, to bowdlerized heroes, to a single halcyon decade, and to limited, noneconomic objectives." lars like Michael A. Chaney, Joanna Davis-McElligatt, Markus Oppolzer, Jorge J. Santos Jr., and Johannes Schmid have shown that we should not discard the powerful lessons the March books can teach us about this pivotal period in US history and its contested memorialization. True, the trilogy may sit uneasily with some readers because of its preoccupation with the past and its advocacy of nonviolent resistance. Granted, advertising it as a "roadmap for another generation," as Lewis did on The Late Show with Stephen Colbert, and dedicating it to "the past and future children of the movement" (the three books' identical dedication) may strike others as overly didactic. And yes, the focus on the "classical" phase of the movement-bracketed by the US Supreme Court's Brown v. Board of Education of Topeka decision in 1954 and the civil rights legislation of the mid-1960s - and its relative neglect of "the interweavings of gender, class, and race" raise difficult question about March's historical conservatism."

5 Robert A. Pratt, Selma's Bloody Sunday: Protest, Voting Rights, and the Struggle for Racial Equality (Baltimore: Johns Hopkins University Press, 2017), 4.

6 Jacquelyn Dowd Hall, "The Long Civil Rights Movement and the Political Uses of the Past," Journal of American History, 91, 4 (2005), I 233-63, I 235.

7 Ta-Nehisi Coates, We Were Eight Years in Power: An American Tragedy (New York: One World/Random House, 2017).

${ }^{8}$ Hall, I 234 .

9 Hall, I234, attributes the term "classical" phase to Bayard Rustin and identifies 1954-65 as the timeframe. 
Despite these caveats, the March books deserve critical scrutiny as they join other graphic memoirs of the movement - such as Ho Che Anderson's King (1993-2002); Mark Long, Jim Demonakos, and Nate Powell's The Silence of Our Friends (2012); and Lila Quintero Weaver's Darkroom (2012) - in transposing movement history into graphic form. ${ }^{10}$ They reiterate but also complicate the master narrative, not so much by extending what Martin and Sullivan criticize as "a limited, all-too-familiar repertoire of events, places, and people," " i but by negotiating the many layers of mediation and remediation that constitute what we have come to understand as the civil rights movement: by remediating what Leigh Raiford in her work on civil rights photography calls the "mediamediated events" that shape our sense of the movement. ${ }^{12}$ Using the tools of graphic storytelling, the March books alert us to the highly mediated "process by which history is told and retold, produced and reproduced, and narrativized and renarrativized before becoming enshrined in our memories and disseminated for sociopolitical purposes." "3 They enact "a metacritical awareness of history as an editorial and curative process" by constructing an account of the movement that also serves as a critical engagement with its initial mediation, particularly through photographs and television footage, and as a retroactive memorialization through graphic remediation. ${ }^{14}$ Moreover, they elicit a "metacritical pedagogy" that empowers them as didactic tools for investigating representations of American history, ${ }^{15}$ the workings of social protest movements, and the moral questions that continue to haunt us in the present.

In the following, I distinguish between the didactic impulses of the books and their usefulness as a didactic resource in current pedagogical settings. I begin with a look at the books' didactic impulses. As suggested by the title of Hasan Kwame Jeffries's Understanding and Teaching the Civil Rights Movement (2019), it is crucial to understand how they excite, engage, educate, encourage, enable, empower, and enlist their readers before we think more specifically about how to implement their lessons in the classroom. ${ }^{16}$

10 All of these works are discussed in Jorge J. Santos Jr., Graphic Memories of the Civil Rights Movement: Reframing History in Comics (Austin: University of Texas Press, 2019).

${ }^{11}$ Waldo E. Martin Jr. and Patricia A. Sullivan, "Introduction," in Julie Buckner Armstrong, Susan Hult Edwards, Houston Bryan Roberson and Rhonda Y. Williams, eds., Teaching the American Civil Rights Movement: Freedom's Bittersweet Song (London: Routledge, 2000), xi-xviii, xiv.

${ }^{12}$ Leigh Raiford, “'Come Let Us Build a New World Together': SNCC and Photography of the Civil Rights Movement," American Quarterly, 59, 4 (2007), i I 29-57, i I 50. See also Raiford, Imprisoned in a Luminous Glare: Photography and the African American Freedom Struggle (Chapel Hill: University of North Carolina Press, 20 I I).

${ }_{13}$ Santos, 3. ${ }^{14}$ Ibid., 3 .

${ }^{16}$ I base this list of didactic goals on Armstrong et al., xii; Raiford, "“Come Let Us Build'," II I I. 


\section{DIDACTIC IMPULSES}

The March books tell the life story of US Congressman John Lewis from his childhood in poor rural Alabama to his seminal role in the black freedom struggle of the r 950 s and 1960s. As a former president of SNCC and the only still living member of the "big six," Lewis is at once an eyewitness to some of the movement's most important moments and a historical figure whose legacy the graphic memoir celebrates. ${ }^{17}$ We can identify his triple role as participant, politician, and autobiographer as a prerequisite for the narrative since Lewis's life is inextricably connected with the national past and because the retelling of this past is both a personal and a political project. March: Book One visualizes this connection in an image of present-day Lewis with a visitor and her children in his office in Washington, DC. ${ }^{18}$ $\mathrm{He}$ is gesturing toward a wall filled with photographs as he is about to tell a story about his childhood. Lewis is used to narrating such stories, it seems, and he has already assembled a comic-book-like version of his life - a sequence of framed images - on that wall. ${ }^{19}$ Instead of pretending to offer a strictly factual account of the movement, the scene introduces a sense of self-awareness about its status as a graphic narrative that remediates an already multiply mediated biography. This narrative self-consciously emerges from the Congressman's personal experiences and convictions, but it pursues a broader agenda, offering lessons about the civil rights struggle especially for the younger generation.

The scene in Lewis's office also teaches us a lesson about genre. As a graphic memoir, March belongs to the realm of creative nonfiction and differs from scholarly studies of the civil rights movement, in terms of both how it narrates the story and the evidence it enlists. This generic middle ground - personal recollection, historical accounting, creative depiction - opens up a productive line of inquiry into the very nature of constructing autobiographically inflected history in graphic narrative. This is crucial because both scholarly accounts and graphic nonfiction rely on the same image archive, especially photographs and television footage that "have shaped and informed the ways scholars,

17 In addition to Lewis, who was recently diagnosed with pancreatic cancer but has vowed "to do what I know to do and do what I have always done: I am going to fight it and keep fighting for the Beloved Community," the "big six" included Asa Philip Randolph, Martin Luther King Jr., James Farmer Jr., Whitney Young Jr., and Roy Wilkins. Congressman John Lewis, "Rep. John Lewis Undergoing Cancer Treatment," press release, 29 Dec. 2019 , at https://johnlewis.house.gov/media-center/press-releases/rep-johnlewis-undergoing-cancer-treatment.

${ }^{8}$ Lewis, Aydin and Powell, March: Book One, i 9.

19 Cf. Michael A. Chaney, "On the Nature of the Boundary in Comics Memoir: The Case of March," in Matthias Harbeck, Linda-Rabea Heyden and Marie Schröer, eds., Comics an der Grenze: Sub/Versionen von Form und Inhalt (Berlin: Bachmann, 2017), 49-58, 56. 
politicians, artists, and everyday people recount, remember, and memorialize the 1960 s freedom struggle." 20 That we are perusing a collaborative work by John Lewis, Andrew Aydin, and graphic artist Nate Powell complicates notions of autobiographical authenticity and direct access to personal memory. It is Powell's visuals that set the tone of the narrative, rendered by an artist who was born after the heyday of the movement and who, like Andrew Aydin, cannot draw on his own memories to craft the story.

A scene in March: Book Two addresses this complex intermixture of recounting, remembering, and memorializing the movement. The year is 1962, and John Lewis, as field secretary of SNCC, is leading a protest against a racially segregated public pool in Cairo, Illinois. Presenting a subjective account of this event might have granted Lewis special narrative authority and political credibility as an eyewitness, but the depiction foregrounds the fact that historical access to the event depends on multiple layers of mediation and remediation. A small inset panel on the left shows SNCC photographer Danny Lyon, a white Jewish New Yorker who covered the protest for SNCC's Photo Agency, founded to retain maximum control over the documentation and presentation of the group's activities and deliver raw material for media campaigns. ${ }^{21}$ Lyon took a photograph that would became "probably the most popular poster of the movement" when, ${ }^{22}$ in 1963, SNCC cropped the image, added the slogan "Come Let Us Build a World Together," and sold I 0,000 copies of it. ${ }^{23}$ Powell remediates the image on the same page (Figure I).

The visual depiction of this photograph in March differs from the rest of the page, indicating a chain of mediations and remediations from photographic image to poster to graphic memoir. This chain precludes any clear distinction between historical event, its initial photographic mediation, and its later narrativization for various political purposes. ${ }^{24}$ It motivates a look into the many media representations of the movement, turning readers into active sense makers by prodding them to grasp the nature and scope of the movement's visual archive. This includes SNCC's practice of hiring "field workers with cameras" like Lyon, whose photographic records were not only widely

${ }^{20}$ Raiford, "CCome Let Us Build'," I 130.

2 I Ibid., I 139.

22 Lewis, Aydin and Powell, March: Book One, r 20. The phrase is taken verbatim from John Lewis with Michael D'Orso, Walking with the Wind: A Memoir of the Movement (New York: Simon \& Schuster, 1998), 192. Lewis's author biography at the end of March mentions the autobiography but does not identify it as a source text. Cf. Markus Oppolzer, "John Lewis's March: Promoting Social Action through Comics," in Bernd Dolle-Weinkauff, ed. Geschichte im Comic (Berlin: Bachmann, 2017), 225-38, 23 I-32.

23 Raiford, "Come Let Us Build'," I 133.

24 The poster can be viewed at https://digitalcollections.usm.edu/uncategorized/ digitalFile_8632ef66-IIa8-43c5-92b4-a2II286d80c5; the photograph is available at https://www.crmvet.org/images/plyon.htm. 

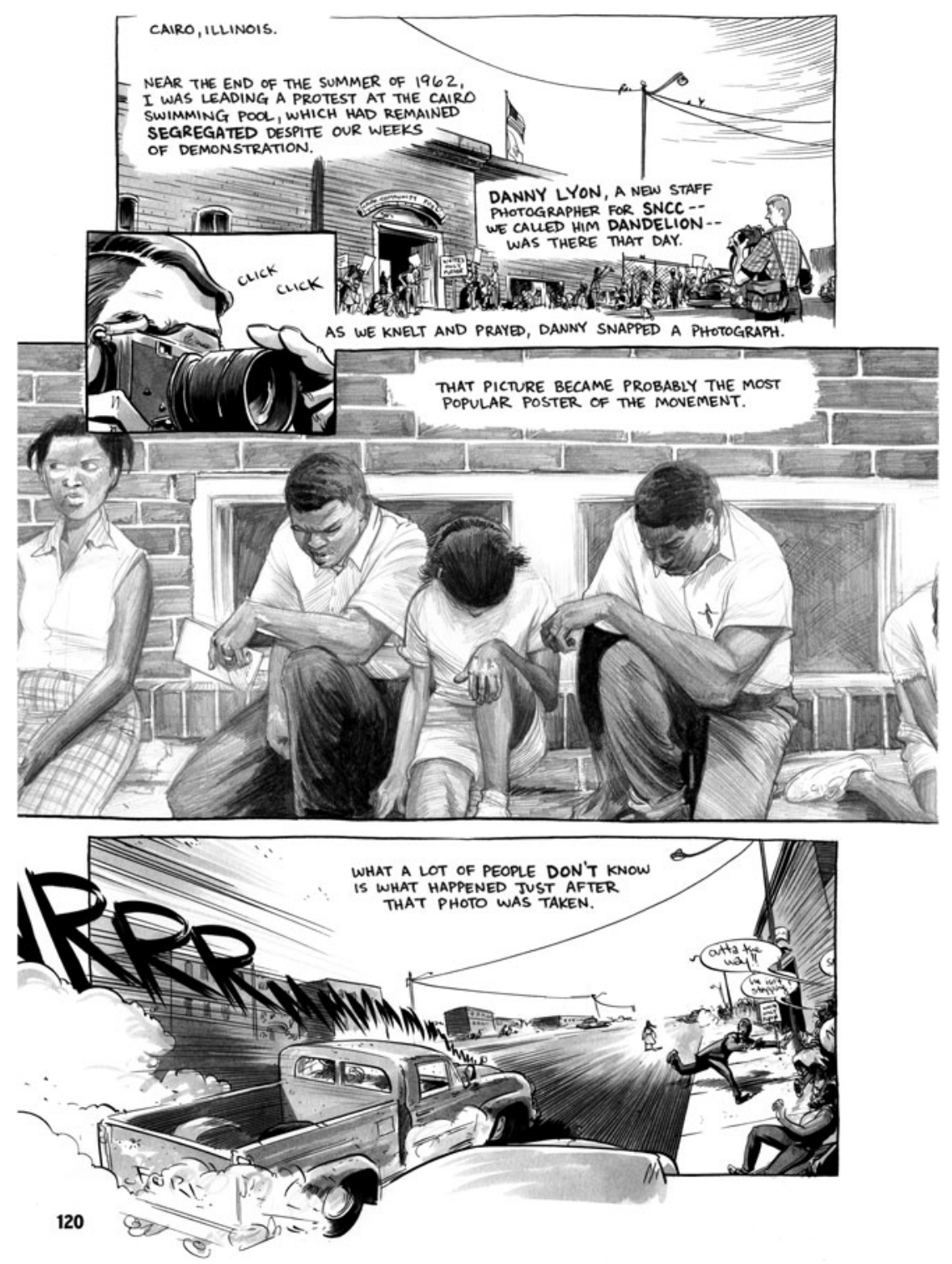

Figure I. March (C) John Lewis and Andrew Aydin, courtesy Top Shelf Productions/IDW Publishing.

circulated but also repeatedly reframed by different institutions, from SNCC's "propaganda machine" to newspapers like the New York Times and the Washington Post. ${ }^{25}$

${ }^{25}$ Raiford, “"Come Let Us Build'," I I 39, I I 4 I. 
As active sense makers, attentive readers will discern a discrepancy between the original photograph and the poster, both of which March evokes. Whereas the poster centers on three kneeling figures - a girl flanked by two young men, the one to the viewer's left being John Lewis - the photograph shows another girl to Lewis's right. Transforming Lyon's photograph into the poster, Lyon or someone at SNCC cropped the image and erased this other, thirteen-year-old, girl from the visual narrative, literally placing her outside the political frame. ${ }^{26}$ But March rehabilitates her as a central figure of the protest by providing a fuller sequence, and not just an isolated image, of events already recalled in Walking with the Wind, as they visualize "what happened just after that photo was taken." ${ }^{27}$ The medium of graphic narrative is especially suited to such visualization, as panels sequentially arrest specific moments of an ongoing action. In the extended scene in March, we see a pickup truck racing toward the courageous girl whom SNCC had erased from the poster. She is standing in the street, steadfastly facing the approaching vehicle as others are scooting away from its dangerous path. The truck suddenly stops, then speeds away, leaving the injured girl behind.

This sequence represents a complex co-presence of personal memory, recorded history, and creative memorialization. Recorded by Lyon's camera in 1962, remediated in the following year through the SNCC poster, recalled in prose memoirs by Lewis and Lyon (the latter of which ironically reprints the poster but not the original photograph ${ }^{28}$ ) in the late 1980 s and early 1990 , and then re-remediated through Powell's drawings, the Cairo protest has obviously been widely visualized. But as the scene in March alleges, photograph and poster only provide a glimpse of the event; they are only snapshots whose iconic power stems precisely from their status as single images that absent more than they present (even though Lyon took other, less well-known photographs that day). Moreover, it is impossible to gauge to what extent Powell's representation is based on the photograph, the poster, or Lyon's and Lewis's memories of the moment. This complicates Lewis's status as an autobiographer as personal memories of the past intersect with proliferating media images and narrative accounts. As we can learn from this depiction, while March may be complicit in the master narrative of the movement, it also reveals its reliance on different forms of mediation and remediation, venturing beyond dominant images and including protest that took place outside the South. ${ }^{29}$

${ }^{26}$ Cf. Danny Lyon, Memories of the Southern Civil Rights Movement (Santa Fe: Twin Palms, 2010), 26. $\quad{ }_{27}^{27}$ Lewis, Aydin and Powell, March: Book Two, I $20 . \quad{ }^{28}$ Lyon, 26.

${ }^{29}$ Hall, "The Long Civil Rights Movement," I 239, criticizes the "trope of the South as the nation's 'opposite other,' an image that southernizes racism and shields from scrutiny both the economic dimensions of southern white supremacy and the institutionalized 
March, moreover, is "a memoir that also serves as a recruitment tool for political activism" rather than merely an attempt at graphically documenting American history. ${ }^{30}$ We must therefore situate the trilogy vis-à-vis a vast archive of verbal, visual, and audiovisual treatments of the movement, where emancipatory narratives struggle against a long history of racist caricature to challenge the "historical archive of racist visualization." ${ }^{1}$ I In this context, the photograph at the end of all three March books that shows Lewis with his arms around the white Aydin and Powell as they are standing on the Edmund Pettus Bridge in Selma, the scene of the pivotal showdown between the black protesters and the state troopers in 1965 , is simultaneously provocative and reconciliatory. By presenting the long-term effect of this showdown as a "friendship [that] is not only interracial but also cross-generational," ${ }^{32}$ the photograph strikes a note of reconciliation and dreams up a racially inclusive America, dismissing opposing notions of divisiveness and racialized hatred. It superimposes an image of harmonious collaboration over the violence and suffering that are so vividly captured throughout the civil rights archive.

These tensions also shape the graphic memoir's didactic impulses. Speaking to Sarah Jaffe, Aydin named "inspiring young people to get involved and also teaching them the tactics" as a central aim. ${ }^{33}$ In another interview, he claimed, "Our goal was to use this to teach and inspire another generation." ${ }_{34}$

patterns of exploitation, segregation, and discrimination in other regions of the country." On movement photography beyond the South see Mark Speltz, North of Dixie: Civil Rights Photography beyond the South (Los Angeles: Getty, 2016); on extending the story of the movement to northern campaigns see Patrick D. Jones, "Place Matters: The Indispensable Story of Civil Rights Activism beyond Dixie," in Hasan Kwame Jeffries, ed., Understanding and Teaching the Civil Rights Movement (Madison: University of Wisconsin Press, 2019), 95-1 1 0. Anderson's King covers Martin Luther King Jr.'s attempts to bring the movement to Chicago. See Ho Che Anderson, King: A Comics Biography (Seattle: Fantagraphics, 2010), i 54-98.

30 Oppolzer, 235.

${ }^{31}$ Michael A. Chaney, "Is There an African American Graphic Novel?", in Stephen E. Tabachnik, ed., Teaching the Graphic Novel (New York: MLA, 2009), 69-75, 73. On this archive see Michael D. Harris, Colored Pictures: Race and Visual Representation (Chapel Hill: University of North Carolina Press, 2003); Fredrik Strömberg, Black Images in the Comics: A Visual History (Seattle: Fantagraphics, 2003); on African American responses see Rebecca Wanzo, The Content of Our Caricature: African American Comic Art and Political Belonging (New York: New York University Press, 2020).

32 Johannes C. P. Schmid, "Graphic Nonviolence: Framing 'Good Trouble' in John Lewis' March," in Astrid Böger and Nicole Maruo-Schröder, eds., Envisioning Justice: Mediating the Question of Rights in American Visual Culture, special issue of European Journal of American Studies, I 3, 4 (2018), at https://journals.openedition.org/ejas/ I 3922.

33 Sarah Jaffe, "John Lewis' Advice for Young Activists: March," In These Times, 13 Aug. 201 3 , at http://inthesetimes.com/article/I 5460/john_lewis_advice_for_young_activists_march.

${ }^{34}$ Laura Hudson, “The Civil Rights Legend Who's Inspiring a New Generation with Comic Books," Wired, 2 I Jan. 201 5, at www.wired.com/2015/01/john-lewis-march-comic. 
The cross-generational framing of the narrative and the urge to teach the lessons of the past-especially nonviolent resistance against state-sanctioned discrimination - suffuse the paratextual packaging of the three volumes, bringing us closer to the narrative without yet immersing us in it. Gérard Genette defines paratext as everything that is materially adjacent to but not directly part of the narrative proper-book titles, cover illustrations, epigraphs, introductions and afterwords, footnotes - and understands it as "a zone not only of transition but also of transaction" between the text and the outside world, between author and reader. ${ }^{35}$ The March books invite us into this zone with a profusion of paratextual matter, choosing first and foremost a title that wavers between historical event, movement tactic, moral imperative, and temporal reference. The title evokes forms of mass protest like the March on Washington for Jobs and Freedom (1963), where Martin Luther King Jr. delivered his famous "I Have a Dream" speech, ${ }^{36}$ and where Lewis voiced his indictment of American racism, as well as the March to Selma over the Edmund Pettus Bridge (1965), which serves as the climax of the trilogy. It also captures the ethics of nonviolent resistance: marching through segregated areas without fighting back against white aggressors, meeting racist hatred with Christian love. As an imperative, it calls on young Americans to embrace marching as an appropriate means of voicing dissent, compelling them to battle injustice through peaceful activism. Finally, the confrontation between the protesters and the Alabama state troopers that came to be known as Bloody Sunday took place in March, adding temporal depth to the title's associative web of meanings. ${ }^{37}$

The trilogy paratextually presents Lewis's life story as a paean to an exceptionally American type of heroism that rewards a nonviolent marcher with a political career and a black President. To justify this trajectory, March evokes the rags-to-riches story and its African American variant, the story of racial uplift in the tradition of Booker T. Washington. The inside flap of Book One features a photograph of Lewis and a biographical sketch that identifies him as an "American icon." His "commitment to justice and nonviolence," the sketch alleges, "has taken him from an Alabama sharecropper's farm to the halls of Congress, from a segregated schoolroom to the 1963 March on

35 Gérard Genette, Paratexts: Thresholds of Interpretation (Cambridge: Cambridge University Press, 1997), 2.

${ }^{36}$ Martin Luther King Jr., "I Have a Dream," in A Testament of Hope: The Essential Writings and Speeches of Martin Luther King, Jr., ed. James M. Washington (New York: HarperCollins, 2003), 208-16.

37 It took three attempts to cross the Edmund Pettus Bridge as part of the march from Selma to Montgomery: 7 March, which ended in bloodshed; 9 March, led by Martin Luther King Jr., which was aborted; 21 March, when approximately 3,200 people marched across the bridge. 
Washington, and from receiving beatings from state troopers to receiving the Medal of Freedom from the first African-American president." Lewis may have started small by honing his preaching skills before the chickens on the family farm, but he becomes a civil rights leader whose speech at the March on Washington receives extensive narrative space. He is invited to witnesses the signing of the Voting Rights Act by President Lyndon B. Johnson in 1965 and embraces Obama at the beginning of the inauguration ceremony. ${ }^{38}$ This uplift narrative locates Lewis's "personal, political, and moral success ... within the democratic institutions of the United States." 39 Calling Lewis's resistance "revolutionary nonviolence" and suggesting that the "principles and tactics" developed by the movement "remain vitally relevant in the modern age," the sketch tries to have it both ways by characterizing Lewis as a revolutionary and a member of the political establishment. Yet what can, with some legitimacy, be debunked as an overly optimistic narrative that downplays the problems of the present and silences more aggressive efforts to fight for justice (such as the Black Panther Party) can also be read as an act of resistance against another master narrative that claims the demise of the movement in the late 1960s and embraces a false "rhetoric of color-blindness." 40

The cover images of the three books highlight the tension between the uplift narrative and SNCC's "radical pedagogy" by conjuring up key methods of the movement: ${ }^{41}$ sit-ins, demonstrations, freedom rides, and political speeches. ${ }^{42}$ These methods were widely documented at the time, but instead of simply translating archival material into graphic form, the March books interrogate the very process of historical documentation. Lewis appears in every cover image, first in the center of the boycotters at the lunch counter (Book One), then as a speaker at the March on Washington (Book Two), then as one of the protest leaders on Bloody Sunday (Book Three). While he is clearly presented as the key figure, his graphic avatar does not completely dominate the images. He is usually depicted as part of the movement, appearing as a leader whose effectiveness depended on fellow activists to risk their lives by joining the boycotts, signing up for the rides, attending speeches, and marching. The covers thus support Santos's conclusion that March is "more than the memoir of one great man - it is the biography of a movement." 43 They mobilize the same tension between personal

${ }^{38}$ Lewis, Aydin and Powell, March: Book One, 27-28; Lewis, Aydin and Powell, March: Book Two, 166-71; Lewis, Aydin and Powell, March: Book Three, 240-43; Lewis, Aydin and Powell, March: Book Two, 5 I.

${ }^{40}$ Hall, "The Long Civil Rights Movement," I 238.

39 Schmid, 5 .

${ }^{42}$ My analysis of the covers is indebted in part to Chaney, "Misreading with the President."

43 Santos, Graphic Memories, $5 \mathrm{I}$. 
success story and political history that informs the subtitle of Lewis's Walking in the Wind: Memoir of the Movement. In fact, if the cover of the first edition of Walking in the Wind focussed singularly on Lewis, playing into the "greatman" approach to history, a later edition (Harcourt Brace, 1999) combined the portrait of Lewis on the top with a photograph of the standoff on the Edmund Pettus Bridge, prefiguring the top-to-bottom structure of the first two March covers. The covers of both the prose autobiography and the March trilogy therefore mobilize the dominant narrative of the movement the focus on "charismatic personalities (who were usually men) and telegenic confrontations ... in which white villains rained down terror on nonviolent demonstrators dressed in their Sunday best" 44 - while suggesting that there is more to this narrative than meets the eye.

Equally noticeable is the trifurcated mise en page that shapes all three covers even as their architecture shifts from the first two books to the third. The cover of Book One shows the protesters at a lunch counter at the bottom (Figure 2). The title and the names of the authors divide the lower third of the cover from its upper third, which shows people marching with their heads or upper torsos truncated by the upper end of the book. The image in the upper third of the cover evokes a photograph by Charles Moore that shows marchers from the waist down en route to Montgomery, Alabama in 1965.45 This is not the first time we encounter marching feet and legs in graphic narratives of the movement. Nate Powell had already chosen this motif in The Silence of Our Friends, and Lila Quintero Weaver uses a very similar depiction in Darkroom, suggesting that these graphic memoirs share a common iconography. ${ }^{46}$

Chaney holds that the "arrangement of images and texts [on the cover] ... puts th $[\mathrm{e}]$ very tension between past and present, words and images, doing and looking on prominent display." 47 The only way to come to terms with this tension is to perform repeated acts of closure, which Scott McCloud defines as "observing the parts but perceiving the whole" and as "mentally completing that which is incomplete based on past experience." ${ }^{8} 8$ Acts of mental completion induced by the cover of Book One include the need to attach full bodies to the feet of the marchers and connect these bodies with the civil rights

44 Hall, 1236.

${ }^{45}$ Charles Moore and Michael S. Durham, Powerful Days: The Civil Rights Photography of Charles Moore (New York: Stewart, Tabori \& Chan, I991), I 55.

${ }^{46}$ Mark Long, Jim Demonakos and Nate Powell, The Silence of Our Friends (New York: First Second, 2012), 126; Lila Quintero Weaver, Darkroom: A Memoir in Black \& White (Tuscaloosa: University of Alabama Press, 2012 ), I 40.

47 Chaney, "Misreading with the President," 28.

${ }^{48}$ Scott McCloud, Understanding Comics: The Invisible Art (New York: HarperCollins, 1994), 63. 




Figure 2. March (C) John Lewis and Andrew Aydin, courtesy Top Shelf Productions/IDW Publishing.

demonstrations. They entail processing the possible disjuncture between the reductive assumption that all protesters were African American and the presence of a white boycotter in front of the lunch counter. Enticing an active 
reception by figuratively reopening the closed lunch counter through a call for closure, the cover challenges readers to consider their own implication in the nation's history of racial segregation. It places viewers behind the counter, on the "white" side of history, while also setting them in opposition to the two white servers, whose bisected faces stare at them from the left and right edges of the image, asking either to be made whole again or to be pushed aside, and thus out of the frame, to create further space for the viewer to gaze at the scene.

The cover of Book Two retains the structural setup of the first cover, portraying Lewis in mid-speech at the bottom as he is facing the Washington Monument and addressing the marchers who had gathered around the reflecting pond on 28 August 1963 as part of the March on Washington (Figure 3). The upper third of the image remediates a photograph of a burning Greyhound bus transporting freedom riders to Alabama, taken near the city of Anniston on Mothers' Day on I4 May 196I.49 In conjunction with the lower third, the cover signals the multipronged tactics of the movement from political speeches to grassroots voter registration, and it announces its increasing intensity, including a violent backlash, as things are literally heating up. This increase, and the rising tension in the overall narrative, are indicated by the middle section of the cover (title, author names), which is tilting slightly upwards to the right. Chaney maintains that "the dual cover imagery of the first two books champions a recovery project that refuses to differentiate between causes and effects" since it is impossible to determine whether the incineration of the bus depicted in the upper section of the cover of Book Two caused Lewis's appearance in Washington or vice versa. ${ }^{\circ}$ Without a certain telos, different temporalities "collapse ... into the paradoxes of revolutionary time"; they embody a "chronotopos of black revolution" that is steeped in the popular iconography of the movement but refuses to be limited by it. Juxtaposed with more recent media images of burning vehicles, such as those of the Ferguson unrest after the killing of Michael Brown on 9 August 2014, they might indeed evoke Amiri Baraka's notion of "nation time," the "sense that African Americans are no longer outside of history but at its center." ${ }^{\prime}$

The third and final cover of the trilogy almost abandons the established structure by positioning the black protesters even more clearly at the center of American history (Figure 4). It presents only a single image of the marchers

49 For a reconstruction of the events of that day and the activities of the Freedom Riders see Raymond Arsenault, Freedom Riders: $196 \mathrm{I}$ and the Struggle for Racial Justice (Oxford: Oxford University Press, 2006).

so Chaney, "Misreading with the President," 33.

${ }^{51}$ Ibid., 32, 35 . 


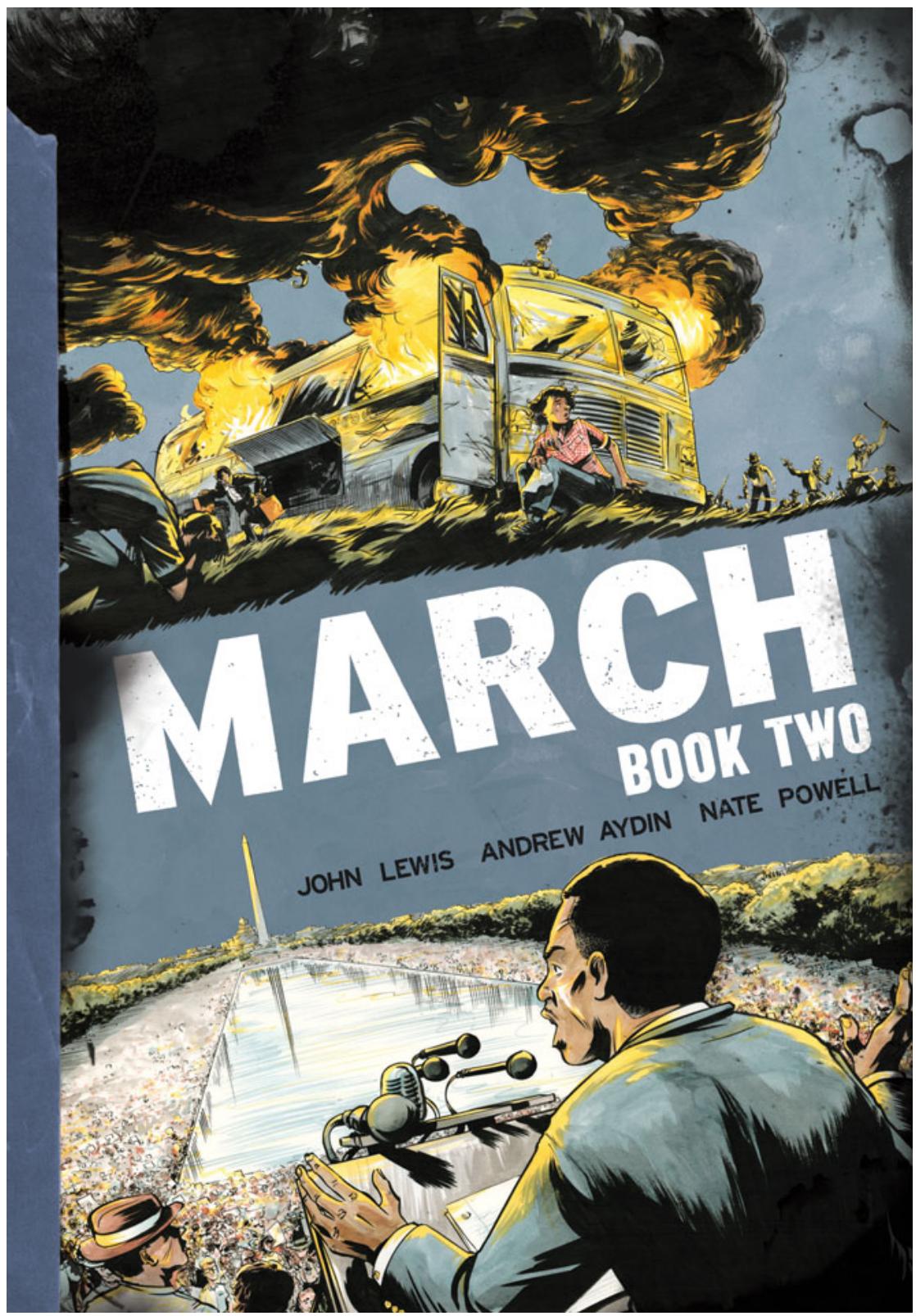

Figure 3. March (C) John Lewis and Andrew Aydin, courtesy Top Shelf Productions/IDW Publishing.

heading toward heavily armed state troopers, and the title/author section points upwards at such a degree as to be almost vertical. Rather than establish a contrast to the first two covers, the image offers a compressed visualization of 


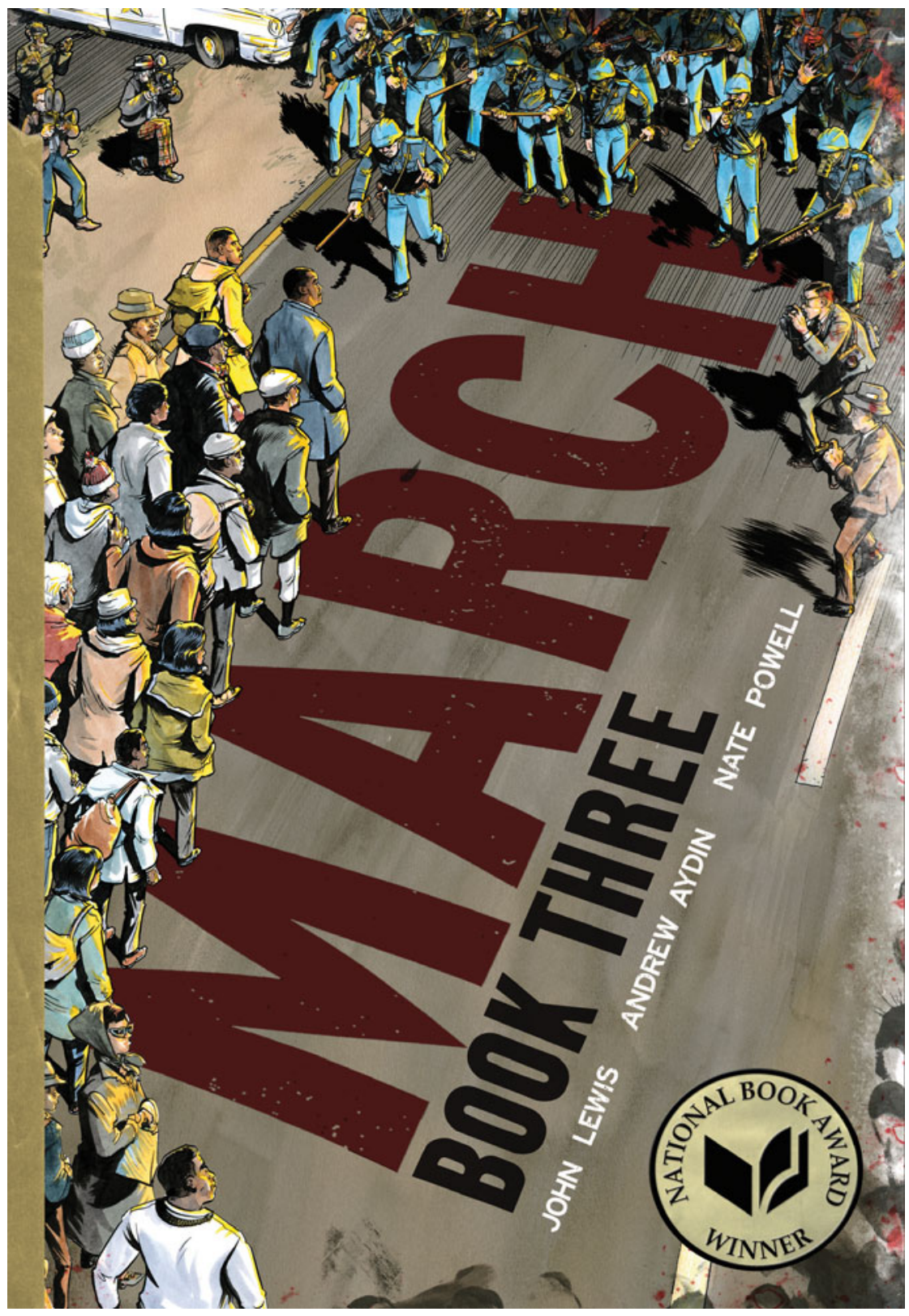

Figure 4. March (C) John Lewis and Andrew Aydin, courtesy Top Shelf Productions/IDW Publishing.

a critical moment in US history that retains a sense of division even as it seeks to transcend it, suggesting the possibility of progress confronting resistance. In fact, the cover literalizes Genette's definition of the paratext as a zone of 
transition and transaction by depicting the confrontation between troopers and protesters as a shift in US race relations (transition) while, at the same time, creating an image that admonishes us to turn the recognition of racial injustice into an inspired form of political protest (transaction). Placing television cameramen and press photographers at the sides of the road, the cover introduces a third party into the equation, a party that does not appear on the covers of the first two books but played a significant role in changing public sentiment toward the movement. In this historical moment, race-based segregation - metonymically represented through the trifurcated structure of the covers, with the book title serving as a metaphorical color line-is about to give way to a more inclusive sense of national cohesion. As the marchers are approaching state troopers who have already drawn their weapons, this is a hopeful scene only if we understand its significance as a memory of the movement's longue durée. We already know that the marchers will be brutally beaten and that it will take more action and resolve to gain legal equality through federal legislation, not to speak of the elusive goal of full social and economic justice.

Ironically, the image does not bring us closer to the action but chooses a cinematic high-angle viewpoint that takes us away from the confrontation. This perspective transports us from the sense of immediate implication created by cover of Book One and the broadened scope of Book Two to an "ennobled perspective of the voyeur," foregrounding a "voyeuristic tension that has been anticipated by the presence of the media." ${ }_{52}$ It changes the focus from the movement to its mediation and memorialization and casts us either as voyeurs, as Chaney suggests, or as metacritical observers aware not only of the movement but also of its initial mediation and ongoing remediation. As voyeurs, we might appreciate Powell's beautiful graphic rendition or find solace in the successes of the movement, from civil rights legislation to the election of the nation's first black President. As metacritical observers, however, we must account for the narrative framing and material packaging of this account. The covers nudge us in this direction through their inclusion of simulated remnants of tape on the books' spines and what looks like the brittle binding of a library edition or a textbook. Book Two simulates the effect of charred paper, of a cover page partially burned at the seams by the searing heat of the flaming bus, while Book Three even has small splotches of red splattered over the right-hand side of the image as well as on the top and bottom, suggesting either a light effect (reflecting rays of the sun) irritating the quasi-photographic recording of the scene or non-diegetic bloodstains smudging the papery surface of the drawing. As such, they subtly immerse

52 Ibid., 39. 
the reader in the historical moment, suggesting haptic sensations that might make the past seem alive through books that can bleed and burn. These books are meant to be used like Martin Luther King and the Montgomery Story, a comic book published by the Fellowship of Reconciliation in 1957 that served as a political primer and tactical handbook. ${ }^{53}$

Moving from paratexts to the text proper, we may note that March establishes a network of references that contextualize the narrative and communicate historical awareness. The books facilitate further research by including a list of dos and don'ts Lewis composed to provide members of SNCC with protest guidelines and by reprinting the reverend and civil rights activist Jim Lawson's statement of purpose for SNCC. 54 They also incorporate declarations by southern segregationists like Birmingham chief of police Eugene "Bull" Connor and Alabama governor George Wallace, as well as passages from political speeches by Lewis, King, and fellow civil rights advocates. 55 Book Three devotes seven pages to Fannie Lou Hamer's televised testimony at the Democratic National Convention in 1964, which follows speeches by New York governor Nelson Rockefeller and Arizona Senator Barry Goldwater at the Republican Convention. ${ }^{6}$ Frequent radio announcements, television broadcasts, and newspaper headlines underscore the trilogy's claim to accuracy and suggest an archive of recorded and printed materials waiting to be accessed by readers in search of a better understanding of the movement.

Moreover, March evokes the sounds of the movement. In Book One and Book Three, protesters sing "We Shall Overcome," the movement's anthem, whose lyrics express the pining for a life in peace and voice a belief in eventual triumph over racism. ${ }^{77}$ Powell's depiction of the song includes snippets of the lyrics that visualize the singers' dedication to a common cause and their affirmation of community, which are captured by the promise to walk hand in hand. He accomplishes this through singing balloons, or bands, that

53 Fellowship of Reconciliation, Martin Luther King and the Montgomery Story (Marietta: Top Shelf, 20 I 4). The comic contains a graphic biography of King, a story on Rosa Parks's role in the Montgomery bus boycott, and information on the "Montgomery method" of nonviolent resistance. Oppolzer, "John Lewis' March," 232, calls it "a primer that explained the philosophy and the necessary steps involved in organizing protests." See also Joanna C. Davis-McElligatt, "Walk Together, Children': The Function and Interplay of Comics, History, and Memory in Martin Luther King and the Montgomery Story and John Lewis's March: Book One," in Michelle Ann Abate and Gwen Athene Tarbox, eds., Graphic Novels for Children and Young Adults: A Collection of Critical Essays (Jackson: University Press of Mississippi, 2017), 298-3 I I; Santos, Graphic Memories, 53-56.

${ }^{54}$ Lewis, Aydin and Powell, March: Book One, 97; Lewis, Aydin and Powell, March: Book Two, I $8 . \quad$ ss Lewis, Aydin and Powell, March: Book Two, 48, I 24-25, I66-73.

${ }_{56}^{6}$ Lewis, Aydin and Powell, March: Book Three, 107-1 3, 102-3.

57 Lewis, Aydin and Powell, Book One, I03; Lewis, Aydin and Powell, March: Book Three, I 20, 214. 


\section{Daniel Stein}

meander across the page and connect people via visualized sound. These bands function as a leitmotif that we can recognize as a stylistic device Powell had introduced in The Silence of Our Friends, but they also manage to retell a familiar story. They remind us that any account of the movement should include the music that sounded the fears and hopes of the protesters and infused them with the resolve to withstand physical and mental abuse..$^{8}$ The final stanza of "We Shall Overcome" clarifies the connection between future and present, aspiration and action. When the lyrics state that the singers are not afraid today, they mark the moment when the hymns' spiritually grounded hope for a better time in heaven transitions into an expression of earthly resolve.

From a present-day perspective, such references to the music of the movement may seem overly optimistic, especially since they support a teleology that ends with Obama's inauguration. With Obama President, the message seems to be, the protesters have finally overcome the burdens of the past. They are no longer barred from voting in the South but have helped elect the first black President. Book One, Chaney notes,

closes on a note of optimism, of narrative and affective simplicity. The problem at the beginning, of there being no voice loud or legible enough, is solved in the end. Whose American voice speaks louder than that of our black president? History is progressive in this formulation ... and it is also optimistic in a conservative way, perhaps even a radically conservative way. Social problems are to be solved by the official political system. ${ }^{59}$

Yet as Chaney acknowledges, history in March is not always linear, and the musical references underscore a sense of nonlinearity. In jail, the protesters sing to preserve their dignity and irritate the guards. Singing becomes audible as a nonviolent form of resisting dehumanization, creating solidarity among the inmates. ${ }^{60}$ It transforms linear prison time, meant to force them into submission and accepting racial segregation by arresting their ability to act on their beliefs, into nonlinear protest time, subjectively shortening the jail experience by investing it with a transcendent purpose.

The most politically resonant musical reference occurs in Book Two, when soul singer Aretha Franklin performs "My Country 'Tis of Thee" at Obama's inauguration. ${ }^{6 I}$ Not only does the phrase "let freedom ring" echo King's

${ }^{8}$ For historical context see Reiland Rabaka, Civil Rights Music: The Soundtracks of the Civil Rights Movement (Lanham: Lexington, 2016). On using music to teach civil rights history see Gregory Freeland, "Music and the Civil Rights Movement, 1954-1968: A Classroom Approach," in Armstrong et al., Teaching the American Civil Rights Movement, I25-40; Charles Hughes, "Freedom Songs: Building a Civil Rights Playlist," in Jeffries, Understanding and Teaching, 209-23.

${ }^{60}$ Lewis, Aydin and Powell, March: Book Two, 103-7. 59 Chaney, "On the Nature," 54. 6 I Ibid., 79-82. 
"I Have a Dream" speech, but while the patriotic lyrics are flowing from the top left of page 80 to the lower right of page $8 \mathrm{I}$, the narrative of American greatness is undermined by six rectangular inset panels (Figure 5). These panels document the historical sacrifices of the activists and the violations of the nation's foundational creeds by the segregationists. On the page that precedes Franklin's depiction on the steps of the US Capitol, the song's titular opening line appears across the post-protest carnage at a Greyhound station in Montgomery, where a white mob had attacked a group of protesters in 1961. Powell uses the same technique again directly afterwards. As we turn the page, the line "Oh let freedom ring!" carries us from the image of the singing Franklin in the narrative present to the throwing of a Molotov cocktail in the past. According to the sequential logic of comics, Franklin is pointing back to the past, signaling a need to remember history, whereas the white hand that throws the bomb gestures into the future and thus reminds us that it would be foolish to believe that American racism has been overcome. Musical representation therefore complicates the notion of linear time and the hope for a progressive movement toward a better America. ${ }^{62}$ History is linear as well as circular: "Rather than creating paradox," Chaney suggests, "that seeming contradiction reveals how our conception of past experience depends upon circularity, recursivity, even simultaneity." ${ }_{63}$

\section{DIDACTIC IMPLEMENTATION}

Asked about "how to use March - whether to teach it as a primary or secondary source, or something in between," Andrew Aydin downplayed the interviewer's pedagogical challenge:

we worked really hard to make sure that every detail was as accurate as possible. We've been in contact with at least a dozen of the photographers from the movement. You know, folks who were there during the March on Washington, who were there during the early days and the later days. We used an incredible amount of reference photos to make the visuals as accurate as possible. ${ }^{64}$

Aydin's touting of historical veracity clashes with the trilogy's more complex negotiation of media images, personal memory, and collective testimony. If the movement is "the most documented, photographed, and televised political phenomenon in US history," 65 then achieving historical accuracy must be more complicated than Aydin suggests. After all, the polyphony and polysemy

${ }^{62}$ On these images, cf. also Santos, $7 \mathrm{I}^{-74}$.

${ }^{63}$ Chaney, "On the Nature," 55.

${ }^{64}$ Christopher Heaney, "March: Interview with Nate Powell and Andrew Aydin," The Appendix, I, 4 (I 5 Oct. 2013), at http://theappendix.net/issues/2013/10/march-inter view-with-nate-powell-and-andrew-aydin.

65 Santos, 2. 


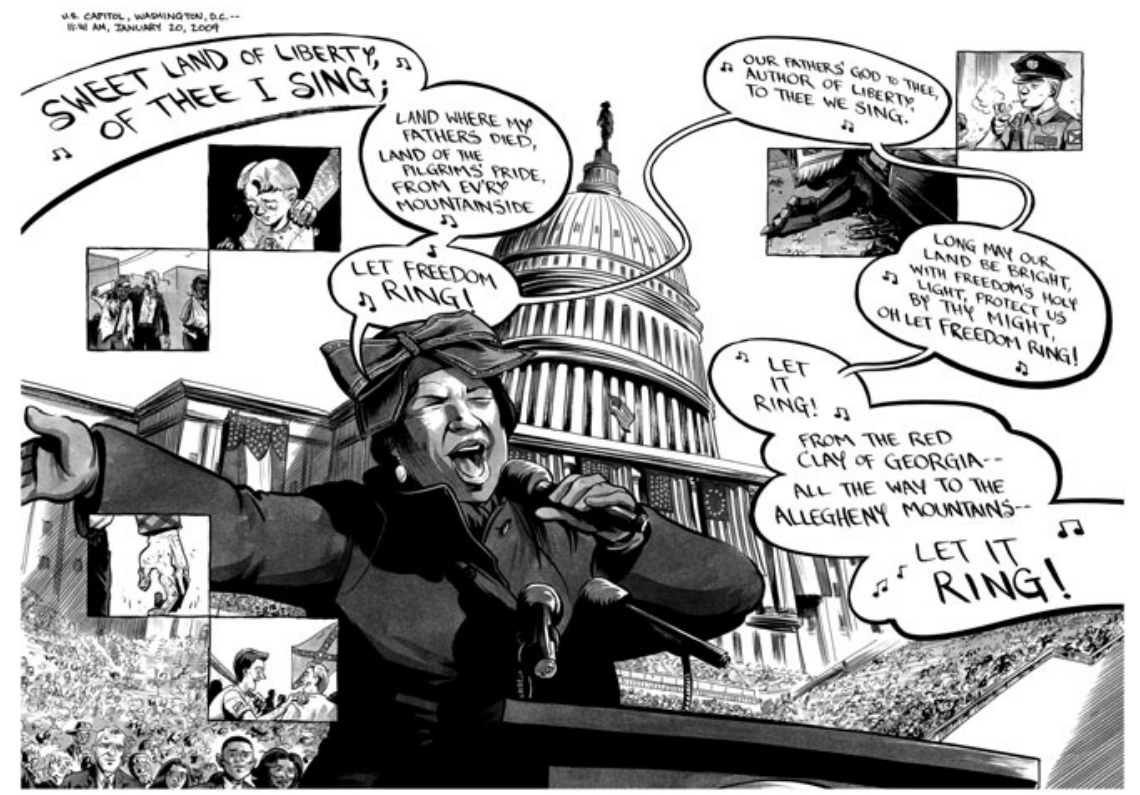

Figure 5. March (C) John Lewis and Andrew Aydin, courtesy Top Shelf Productions/IDW Publishing.

of available images and their incessant remediation make it impossible to reconstruct any singularly authentic narrative. Moreover, if we approach the trilogy from a metacritical perspective that recognizes its repeated remediation of already mediated images, we must go beyond notions of verisimilitude and develop a metacritical pedagogy that is aware of its active role in (re-)shaping public memories of the movement.

Engagements with civil rights memory inevitably participate in "a process of negotiation ... in which meaning of the movement is constantly remade." 66 The discrepancy between Lewis's Superman-inspired promotion of the narrative as an entertaining work - "it's dramatic. It's alive, it's movement, it's action" ${ }^{67}$ - and Aydin's insistence on its documentary ethos certainly points to larger questions about "memorializing the movement" that prove especially vexing "in the arena of popular culture." ${ }^{68}$ But these questions are no less

${ }^{66}$ Renee C. Romano and Leigh Raiford, eds., The Civil Rights Movement in American Memory (Athens: University of Georgia Press, 2006), I.

${ }^{67}$ Joseph Hughes, "Congressman John Lewis and Andrew Aydin Talk Inspiring the 'Children of the Movement' with 'March'," interview, Comics Alliance, 16 Sept. 2013, at https:// comicsalliance.com/congressman-john-lewis-interview-march-andrew-aydin-top-shelf.

${ }^{68}$ Romano and Raiford, xiii, xii. 
vexing in the realm of education, where instructors must make difficult, and politically volatile, decisions about how to frame their lessons and how to access movement historiography with their students. According to Lewis, the books specifically target educators - "It's a lot of fun to get out and talk about this book, and to see the reaction of people, especially teachers, librarians and children"- who might embrace the book as a welcome opportunity to teach their students about American history. ${ }^{69}$

Indeed, judging from the wealth of teaching guides, March is widely present in American high schools and at colleges and universities, which is not surprising considering the popularity of graphic novels and the pedagogical prominence of civil rights history. $7^{\circ}$ Top Shelf Productions even published its own teacher's guide, aimed at Grades 6-I 2 and "extensible to higher education," which didacticizes March in a way compatible with state and national curricular standards. The guide includes before-reading, during-reading, and afterreading activities, as well as worksheets, discussion questions, and links to online sources. ${ }^{71}$

What's more, the books already come with their own didactic devices, as events, places, and people are explicitly named to encourage further research. Book One includes a portrait of Lewis in profile in front of a black background as he is contemplating a powerful message from Jim Lawson. Three short sentences - "His words liberated me. I thought, this is it ... This is the way out" - hover above Lewis's head, and the page design could be taken as an inspiration for student-created single-image portraits of civil rights figures and sentiments associated with them..$^{72}$ Book Two contains biography pages

${ }^{69}$ Hughes, "Congressman John Lewis." On teaching graphic narrative see Lan Dong, ed., Teaching Comics and Graphic Narratives: Essays on Theory, Strategy and Practice (Jefferson: McFarland, 2012); Tabachnik, Teaching the Graphic Novel. For a literary approach see Julie Buckner Armstrong, "Stay Woke: Teaching the Civil Rights Movement through Literature," in Jeffries, Understanding and Teaching, 26I-73.

${ }^{70}$ See teaching guides by Meryl Jaffe (at http://cbldf.org/2014/o2/using-graphic-novels-ineducation-march-book-one); Phil Nast (at www.nea.org/tools/lessons/67442.htm); Jim Haskins, Kathleen Benson, and Benny Andrews (at www.leeandlow.com/images/pdfs/ John_Lewis_tg.pdf); Ronell Whitaker and Eric Kallenborn (at https://classroom.popcul tureclassroom.org/wp-content/uploads/2018/or/MARCH_GUIDE.pdf). The AntiDefamation League also provides instructions (at www.adl.org/education/educatorresources/childrens-literature/march-book-one). Michelle J. Bellino and Darin Stockdill developed a forty-seven-page reading guide for March: Book One geared toward teaching the book in college (at https://sites.lsa.umich.edu/marchingforward/wp-content/uploads/ sites/500/2017/06/MARCH_ReadingGuide.pdf). The website Teachers Pay Teachers offers additional lesson plans (at www.teacherspayteachers.com/Browse/Search:march\% 2oby\%2ojohn\%2olewis).

${ }^{71}$ Peter Gutierrez, A Teacher's Guide to March Book One (Top Shelf Productions), http://cdn. topshelfcomix.com/guides/march-book-one-teachers-guide.pdf.

72 Lewis, Aydin and Powell, March: Book One, 78. 
of A. Philip Randolph and Malcolm X that can be used as a model for assignments to produce similar pages for other members of the movement. ${ }^{73}$ Book Two also reprints the original draft of Lewis's speech at the March on Washington, which students could contrast with the less confrontational speech he actually delivered. ${ }^{4}$ The inclusion of the draft points to the larger project of the trilogy, which is to reiterate, in a popular medium, the "consensus memory" of the period, 75 while also "depict[ing] what is missing from the master narrative." ${ }^{\prime 6}$ As such, the March books are particularly valuable teaching tools that may use the students' familiarity with "the deeply flawed version of the movement" taught around the country as a starting point for a more critical engagement with the historical material and its many mediations and remediations. 77

Such critical engagement could include considering lesser-known members of the movement, such as voter registration organizer Bob Moses, one of the central figures behind the March on Washington; the openly gay Bayard Rustin, another key organizer; as well as women activists like Ella Baker, Diane Nash, Fannie Lou Hamer, and Margaret Moore, all of whom March depicts. Asking whether the trilogy goes far enough in addressing the "hidden meanings [and] omissions" of the master narrative and in supplanting its male hero specter with "a multiplicity of participants across time, gender, socioeconomic backgrounds, and races," could lead to productive class discussions. ${ }^{78}$

A particularly fruitful way to approach the books would be to follow the archival traces created by their intertextual and intermedial references. Of course, readers must be at least aware of this archive before they can "locate the many pasts of Lewis's trilogy, its multiple presents, and complicated racial futures," 79 but the books themselves are fairly explicit about which lines of inquiry to pursue. The story of the freedom rides told in Book Two could launch an investigation into the history and iconography of the movement. The fact that its memorialization includes concrete objects offers opportunities to explore the material legacy and continuing visualization of this historical period. Think of the popular photograph of Rosa Parks, taken by a UPI photographer on 21 December 1956 as an emblem of the

73 Lewis, Aydin and Powell, March: Book Two, I 46, I 49.

${ }_{74}$ The speech is available on YouTube at www.youtube.com/watch? $\mathrm{v}=\mathrm{tFs}$ reTsokJg.

75 Romano and Raiford, $\mathrm{xv}$.

${ }^{76}$ Santos, Graphic Memories, 3.

77 Hasan Kwame Jeffries, "Introduction," in Jeffries, Understanding and Teaching, 3-10, 4.

${ }^{78}$ Derrick P. Alridge, "Teaching Martin Luther King Jr. and the Civil Rights Movement in High School History Courses: Rethinking Content and Pedagogy," in Armstrong et al., Teaching the American Civil Rights Movement, 3-17, 9, 4.

79 Chaney, "Misreading with the President," 26. 
Montgomery bus boycott, or of the photograph of the blazing Greyhound bus near Anniston, remediated on the cover of March: Book Two. Books aimed at young readers like The Story of Rosa Parks and the Montgomery Bus Boycott in Photographs by David Aretha, and Faith Ringgold's If a Bus Could Talk: The Story of Rosa Parks, offer additional material for analysis and creative engagement. ${ }^{8 \circ}$ Another option would be to turn to autobiographical narratives shedding light on areas of the movement that are not commonly included in mainstream historical accounts. Sarah E. Gardner suggests Anne Moody's Coming of Age in Mississippi and Deborah McDowell's Leaving Pipe Shop: Memoirs of Kin as works that grant insights into the lives of people who were not directly active in the movement. ${ }^{81}$ "Not everybody participated in sit-ins, went to jail, or was sprayed by fire hoses and attacked by dogs," Gardner writes, emphasizing "aspects of black life that have been relegated to the margins" and could be salvaged through comparative reading assignments. $^{82}$

In addition to these prose autobiographies, graphic memoirs can support as well as challenge the March trilogy. Lila Quintero Weaver's Darkroom: A Memoir in Black and White offers a Latinx perspective on the struggle for racial integration in Alabama, including the shooting and subsequent death of Jimmy Lee Jackson, which intensified the urge to march to Selma. Created by an Argentinian immigrant whose parents moved to Marion, Alabama when she was five, Weaver's account troubles the black-and-white binary of established movement historiography, introducing "a sliver of gray into the demographic pie" that had previously been "neatly divided between black and white." ${ }_{3}$ Turning to Mark Long, Jim Demonakos, and Nate Powell's The Silence of Our Friends, a semiautobiographical account of a black and a white family in Texas in 1968, offers multiple opportunities for contextualizing the March books. For one thing, this graphic narrative about the friendship between the white television reporter John Long and the college instructor and black activist Larry Thompson (and their families) is told primarily from the perspective of the white reporter. The book thus raises pertinent concerns about interracial solidarity, and it also moves the

${ }^{80}$ David Aretha, The Story of Rosa Parks and the Montgomery Bus Boycott in Photographs (Berkeley Heights: Enslow, 2014); Faith Ringgold, If a Bus Could Talk: The Story of Rosa Parks (New York: Simon \& Shuster, i 999).

${ }^{81}$ Anne Moody, Coming of Age in Mississippi (New York: Laurel, 1976); Deborah McDowell, Leaving Pipe Shop: Memories of Kin (New York: Scribner, 1996).

${ }^{82}$ Sarah E. Gardner, "Coming of Age in the Movement: Teaching with Personal Narratives," in Armstrong et al., 97-1 10, 105.

${ }^{83}$ Weaver, Darkroom, 19. Weaver also remediates pages from the revisionist textbook Know Alabama she had encountered in school. These remediations could be used to encourage students to critically examine their present textbooks. 
action beyond the Deep South into a region not usually at the center of civil rights memory. ${ }^{84}$ Moreover, since it is drawn in a graphic style that is largely identical to March and introduces visual vocabulary that also shapes the trilogy, The Silence of Our Friends reminds us that graphic renditions of the movement are aesthetic and narrative constructs that create the movement even as they seek to document it.

Like the March books, Darkroom and The Silence of Our Friends fashion the story of the movement as an account of its mediation, with Weaver taking her father's passion for photography and filming and the resulting visual archive as a pretext for thinking about the ways in which these technologies impacted the documentary record and shape the narratives afforded by this archive-including scenes in her father's darkroom where we witness the process of developing photographs, recollections of rewinding film footage, and an attempt to retell the events of the night when Jimmy Lee Jackson was killed and "nobody at all got a shot of what happened just one block from our house, on February i 8 , 1965." 5 5 Like Darkroom, The Silence of Our Friends repeatedly shows camera equipment, and it also remediates television footage of the protests, encapsulating the images in panel frames shaped like television screens and showcasing events that remained unrecorded. When a policeman is killed by a ricocheting bullet during a protest, five black students are put on trial for murder, and the case is decided not on the basis of John's camera footage, which did not capture the moment, but on the grounds of John's eyewitness testimony. Both graphic narratives thus emphasize the need to fill gaps in the documentary record with creative nonfiction that draws on various forms of evidence and is also willing to imagine, and graphically represent, what may be missing from the story.

In a college or university setting, frame theory could anchor the analysis. Robert M. Entman defines framing as "essentially involv[ing] selection and salience. To frame is to select some aspects of a perceived reality and make them more salient in a communicating text, in such a way as to promote a particular problem definition, causal interpretation, moral evaluation, and/or treatment recommendation for the item described." 86 Referencing Entman,

${ }^{84}$ Anderson's King is another productive intertext for March (for a teaching guide see http:// cbldf.org/2014/02/using-graphic-novels-in-education-king). It reiterates the master narrative by focussing on King as a leading movement figure but also presents a fragmented, multi-perspectival image of the reverend. Including Howard Cruse's Stuck Rubber Baby (New York: DC Comics, 2010) about growing up white and gay in the South alongside March could introduce questions of sexual orientation and their intersectional significance for reconstructing civil rights movement history, including the controversial claim that the LGBTQ movement is a logical consequence of the civil rights movement. For analysis see the chapters on Anderson and Cruse in Santos.

${ }^{85}$ Weaver, 25.

${ }^{86}$ Robert M. Entman, "Framing: Toward Clarification of a Fractured Paradigm," Journal of Communication, 43, 4 (1993), 51-58, 52. 
Schmid suggests that frames " 'diagnose, evaluate, and prescribe' an event or situation and thus assign causalities, roles, and relations to the actors and objects involved." ${ }_{77}$ In the March books, framing includes the heroic scope of the narrative, and its religious (occasionally messianic) iconography, as well as its political agenda of celebrating nonviolent resistance. ${ }^{88}$ It occurs most forcefully in the celebration of "good trouble" as the most effective form of protest in opposition to more aggressive forms as advocated by Malcolm X, Stokely Carmichael, or Angela Davis, who offered more devastating views of the US and its state institutions than did Lewis. Confronting the text with less heroic, less religiously invested, and less male-centered perspectives, both from the civil rights movement and from our current moment, could facilitate a critical approach to the trilogy without necessarily undermining its narrative achievements. Focussing more specifically on the contributions of women, as M. Bahati Kuumba demands as a way of "looking between the cracks" of the master narrative, could reveal additional forms of "submerged activism" conventionally hidden by the male-centric gender politics of civil rights historiography. ${ }^{89}$ One outcome of these confrontations and new perspectives could be that students learn to recognize structural similarities between the debates within the older civil rights movement over the right course of action and past and current doubts about the effectiveness of peaceful protest, as well as about what Hall calls "the triple oppression of black women - by virtue of the race, class, and gender" - in and beyond the movement. ${ }^{90}$

There is, however, a media-specific aspect we must consider as we think about teaching March. In comics, framing takes a particular form, as Hillary Chute maintains: "while all media do the work of framing, comics manifests

${ }^{87}$ Schmid, "Graphic Nonviolence," 3.

${ }^{88}$ Chaney, "Misreading with the President," 26, discerns "messianic ... exceptionalism."

${ }^{89}$ M. Bahati Kuumba, "Dismantling the Master's Narrative: Teaching Gender, Race, and Class in the Civil Rights Movement," in Armstrong et al., the American Civil Rights Movement 175-91, I82. On gender in the civil rights movement see Vicki L. Crawford, Jacqueline Anne Rouse, and Barbara Woods, eds., Women in the Civil Rights Movement: Trailblazers and Torchbearers, I94I-1965 (Athens: Georgia University Press, 1990); Bettye Collier-Thomas and V.P. Franklin, eds., Sisters in the Struggle: African American Women in the Civil Rights-Black Power Movement (New York: New York University Press, 200I); Davis W. Houck and David E. Dixon, eds., Women and the Civil Rights Movement, 1954-1965 (Jackson: University Press of Mississippi, 2009). On the civil rights movement and \#BlackLivesMatter see Shannon King, "Walking in Their Shoes: Using \#BlackLivesMatter to Teach the Civil Rights Movement," in Jeffries, Understanding and Teaching, 300-I 2.

${ }^{\circ}$ Hall, "The Long Civil Rights Movement," i 247. See also Sheila Pree Bright, \#196oNow: Photographs of Civil Rights Activists and Black Lives Matter Protests (San Francisco: Chronicle, 2018); Laurie Collier Hillstrom, Black Lives Matter: From a Moment to a Movement (Santa Barbara: Greenwood/ABC-CLIO, 2018). 
material frames - and the absences between them."91 Entman's processes of "selection and salience" constitute the basic narrative grammar of comics: the panel border as a frame that has a particular effect on the reader, or the page or double page as a materially framed narrative unit, or shifting points of view as conveyors of meaning. What is selected as the content of a panel and what is excluded are fundamental decisions routinely made in the sequential structuring of the narrative and ensuing acts of closure. Here, Hall's observation that

remembrance is always a form of forgetting, and the dominant narrative of the civil rights movement - distilled from history and memory, twisted by ideology and political contestation, and embedded in heritage tours, museums, public rituals, textbooks, and various artifacts of mass culture - distorts and suppresses as much as it reveals

is particularly pertinent, as graphic narrative is predisposed to visualize the tension between historical suppression (the gutter) and new acts of revelation (the panel). ${ }^{92}$

The confrontation on Bloody Sunday between the protesters and the Alabama state troopers in Book Three uses extensive framing to drive home the books' overall message. It presents an ideal occasion for investigating not only the contents of the narrative but also the mechanisms through which March memorializes the movement and the political implications that follow from this memorialization. In particular, we can detect a shift from the earlier depiction of movement photography, exemplified by Lyon's Cairo photographs and SNCC's poster as cases of self-controlled imagebased agitation, to the "seductive new medium of television" and its less regionally grounded and less grassroots-oriented production and dissemination of moving images. Bloody Sunday was covered by the major news networks and reached a national viewership when the reporting aired on prime time. If the civil rights movement was the networks' "first major ongoing domestic story," then Bloody Sunday was a "point of maximum visibility for the [Selma] campaign as a national news event." "93 Rather than take the television images as documentary raw material against which to assess the depiction in March, students should achieve a critical consciousness about these images. They can improve their media literacy by recognizing that the television reportage was part of an ongoing interaction among television networks, the movement activists, and southern segregationists, playing out in front of a national audience.

${ }^{91}$ Hillary L. Chute, Disaster Drawn: Visual Witness, Comics, and Documentary Form (Cambridge, MA: Belknap/Harvard University Press, 2016), 17.

92 Hall, "The Long Civil Rights Movement," I 233.

${ }^{93}$ Aniko Bodroghkozy, Equal Time: Television and the Civil Rights Movement (Urbana: University of Illinois Press, 2012), 2, I I6. 
For movement leaders like Lewis and King, television was a powerful platform for presenting their case to the American people, even though they had little control over which images were broadcast and how they were framed.

Eleven days after Bloody Sunday and under the impression of television images that showed policemen in Montgomery attacking a mixed group of student protesters on 17 March, King told reporters, "We are here to say to the white men that we no longer will let them use clubs on us in the dark corners. We're going to make them do it in the glaring light of television." 94 The news networks also had a vested interest in broadcasting these images to the nation as they "shared [an] urgent desire to forge a new, and newly national, consensus on the meanings and functions of racial difference." 95 They thus framed the conflict in a double sense. They added the mediaspecific frame of the television camera but also presented the events through the lens of a particular political narrative, both of which shaped the "selection and salience" and "moral evaluation" of the images ${ }^{96}$ - processes that the March books acknowledge by framing well-known footage with the apparatus of the television set.

Before students analyze the depiction of the events in March: Book Three, they should read up on this crucial backstory. These readings (which are always also framings and should be recognized as such) could include Sasha Torres's Black, White, and in Color: Television and Black Civil Rights, Aniko Bodroghkozy's Equal Time: Television and the Civil Rights Movement, or Danielle Smith-Llera's TV Exposes Brutality on the Selma March: $4 D$ an Augmented Reading Experience, the last of which includes original television footage that could be used for further analysis. ${ }^{97}$ The recently launched interactive website www.selmaonline.org, created by the Hutchins Center for African and African American Research at Harvard University, provides intriguing digital inroads into civil rights history. In addition, students should familiarize themselves with comics narratology so that they can identify the intricacies of sequential storytelling and perform the mental processes of closure. Teachers can introduce key terminology and practice its application before turning to March, but they can also use central scenes of the graphic memoir to train their students in basic comics literacy.

Yet how exactly does March: Book Three "diagnose, evaluate, and prescribe" Bloody Sunday as a historical moment of maximum visibility from the vantage point of the present?98 How does it use this moment to memorialize the

94 Quoted in ibid., 2.

95 Sasha Torres, Black, White, and in Color: Television and Black Civil Rights (Princeton, NJ: Princeton University Press, 2003), 6, original emphasis. $\quad{ }^{96}$ Entman, "Framing," 52.

97 Danielle Smith-Llera, TV Exposes Brutality on the Selma March: $4 D$ an Augmented Reading Experience (North Mankato: Compass Point, 2019).

98 Entman, 52. 
movement? It begins by segmenting the account into a sequence of double pages that encapsulate the magnitude of the event and the individual perceptions of the marchers and onlookers through specific panel arrangements and shifting perspectives. The first of these double pages presents a symbolically charged appearance of the bulging Edmund Pettus Bridge. 99 The bridge is shown on the upper third of page 196 from a somewhat removed perspective, as we are witnessing the marchers making their way to the top. On the upper half of page 197 , we are already on the bridge, placed in a slightly elevated overthe-shoulder position that moves us closer to the marchers, who are looking down the declining bridge at the troopers blocking their way. These ascending and descending views of the bridge can be decoded as a reference to drama's rising and falling action; they indicate that the narrative is about to reach its climax and signal that we are entering a particular framing of the depicted events. More significantly, the first image of the bridge foregrounds a press photographer covering the confrontation, which is also why we can interpret (via closure) the second image as a representation of this photographer's point of view or a view close to it. Yet the other panels on the page do not endorse any single perspective; they zoom in and out of the action, combining alternating close-ups of the marchers' faces and the conversation between Hosea Williams and John Lewis with panorama shots of the scene and moving from the protesters' position to the location of the state troopers.

These perspectival shifts suggest a variously photographic, televisual, and cinematic approach. They evoke this sense of photography, televisuality, and cinematography by remediating existing photographs and television footage to signal historical accuracy. The topmost panel on page 195, for instance, which shows the protesters advancing through Selma, is an almost exact remediation of one of Charles Moore's civil rights photographs. ${ }^{100}$ The only differences, apart from the change in medium, are the absent background, which ascribes a sense of temporal transcendence to the image, and the fact that the long line of marchers already begins at the bottom of the preceding page, which underscores the sheer mass of people as well as the page-crossing, visually and politically transgressive, action. Yet the sequential arrangement of these scenes also suggests a filmic sensibility, an effective editing of images from different cameras that ventures beyond documenting the scene into the realm of cinematic dramatization. Ava DuVernay's Selma, released two years before March: Book Three, could serve as the basis for a comparison of Powell's mise en page and the filmic depiction of the encounter on the bridge. ${ }^{\text {Ior }}$ Such a

99 Lewis, Aydin and Powell, March: Book Three, 196-97.

${ }_{100}$ Moore and Durham, Powerful Days, 155.

ror Selma, dir. Ava DuVernay (Paramount, 2014). 
comparison could draw attention to differences in media-specific techniques historically, in terms of movement photography and the televisual depiction of the struggle, as well as presently, in terms of how film and graphic nonfiction memorialize the events.

Pages 198 and 199 bring us even closer to the action, placing us between the protesters and the troopers (Figure 6). They begin by showing the troopers putting on their gas masks and ordering the marchers to disperse. Oversized lettering and scraggly balloons indicate the harshness of the orders. The double page contrasts the aggressive demeanor of the troopers with the peaceful and dignified conduct of the protesters, who react to the commanding officer's denial of their request to speak with the major - "There is no word to be had" - by kneeling down and praying. ${ }^{102}$ The penultimate panel on this page conveys a sense of quiet resolve in the pivotal moment by evacuating everything except the marchers from the image. All of the surroundings, including the panel frame, have disappeared; what counts is the spiritual preparation for what is to come. In McCloud's terms, this missing panel frame is a "bleed": a visual marker that signifies meaning through conspicuous absence. Bleeds occur "when a panel runs off the edge of the page ... [and] time is no longer contained by the familiar icon of the closed panel, but instead hemorrhages and escapes into timeless space." ${ }^{103}$ The March books use panel bleeds to suggest the timelessness of the civil rights movement as a struggle for social and racial equality that cannot be confined to a limited period of US history. ${ }^{104}$

The final panel on the page affords a moment of rest to the protesters and the reader, a piece of calm before the storm about to unfurl as we flip the page. The image is devoid of sound and movement and gives no indication of its duration. It visually captures the fact that the "movement's most consistent and effective gesture against segregation was to contrast the racial terrorism of the South with national ideals and democratic discourses." framing the struggle, the image not only pits the praying protesters against the armed and masked state troopers but inserts between them three cameramen and/or news reporters. This is the third time on this double page that these media representatives appear. They accompany every step of this unfolding drama and raise questions about the instantaneous, real-time memorialization of the movement, including the fact that a photographer like Charles Moore was sometimes "close enough [to the demonstrators] that he wound

\footnotetext{
${ }^{102}$ Lewis, Aydin and Powell, March: Book Three, 199.

${ }^{103}$ McCloud, Understanding Comics, 103.

${ }^{104}$ Santos, Graphic Memories, 64-77, offers extensive analysis of bleeds in March.

ros Torres, Black, White, and in Color, 6.
} 



19

Figure 6. March @ John Lewis and Andrew Aydin, courtesy Top Shelf Productions/IDW Publishing.

up in the frames that other photographers were taking from farther away." 106 Most significantly, they complicate the "ontological status" of the graphic presentation. ${ }^{107}$ Are we reading a comic that is based on Lewis's memories or on the photographic and televisual images that the cameramen had recorded in 1965 and that Powell remediates to establish an authoritative depiction? Can there even be unmediated memories of these moments? What is the connection between the graphic narrative, the historical images on which it draws, and Lewis's recollection of the events, already presented in Walking with the Wind and recounted many times since the mid-1960s? What other eyewitness accounts contributed to the construction of the scene, and what did the photographers Aydin consulted add to the story? All of these questions are useful prompters for classroom activities, from a comparative close reading of Walking with the Wind and March to cross-media analysis of movement photography, moving images, and graphic narrative.

Pages 200 and $20 \mathrm{I}$ zoom in even closer to the action (Figure 7). The first page depicts the transition from prayer to physical violence; the second

${ }^{106}$ Gene Roberts and Hank Klibanoff, The Race Beat: The Press, the Civil Rights Struggle, and the Awakening of a Nation (New York: Vintage, 2006), 317; Raiford, Imprisoned in a Luminous Glare, 81-82.

107 Oppolzer, "John Lewis's March," 228. 


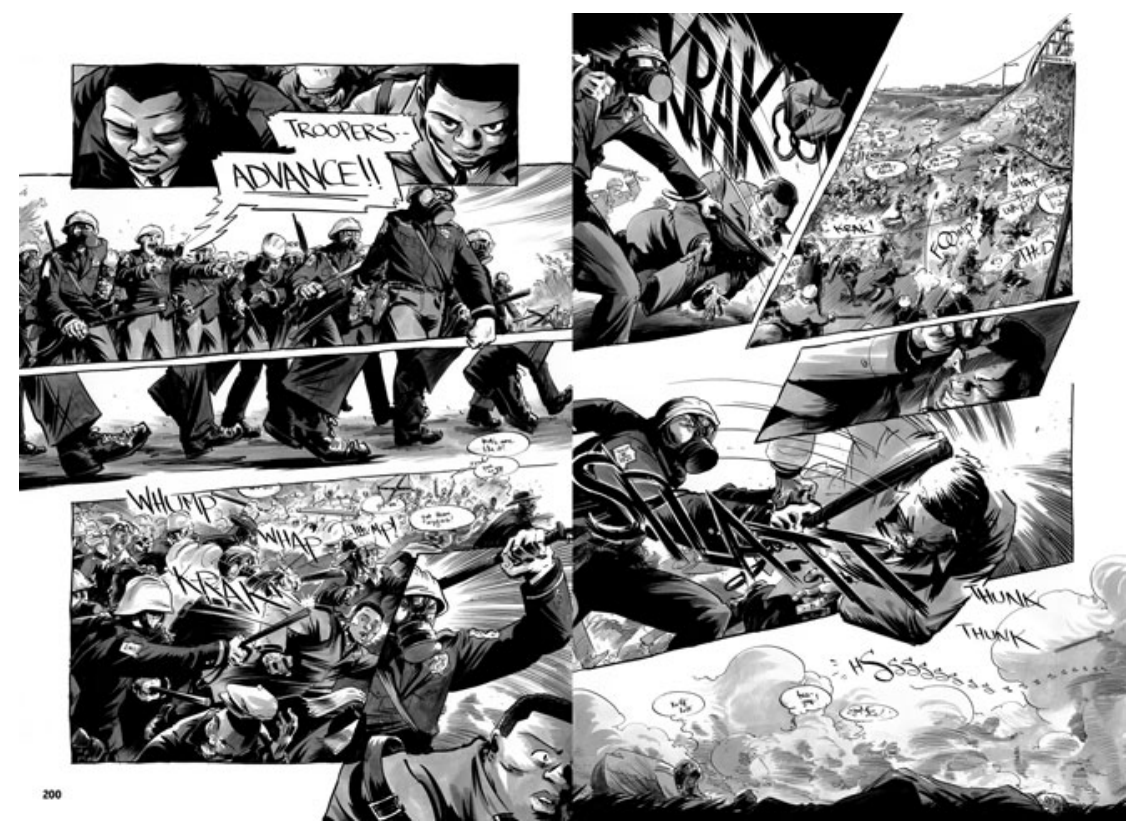

Figure 7. March (C) John Lewis and Andrew Aydin, courtesy Top Shelf Productions/IDW Publishing.

shows the initial attack, focussing on Lewis as he is beaten and falls down, his backpack flying through the air. The troopers emerge as the aggressors here, as their leader issues the order for the attack ("Troopers - advance!!") and as they use batons and tear gas against the unarmed protesters. In terms of layout, the relatively ordered structure of the preceding pages gives way to a more crowded, hectic panel arrangement. These panels' increasingly irregular shapes evoke a sense of brokenness, like shards of glass splintering from a smashed window. It is as if the images are bursting out of the sequence suggested by conventional comic-book narrative, as if they were shattering a television screen that can no longer contain these horrific events. Viewpoints oscillate between extreme close-ups of Lewis's face, medium shots juxtaposing legless troopers with the marchers' metonymic feet, and long shots simulating the confusion of the moment while affording us a more distanced view of the carnage. While the storytelling is effective in its attempt to immerse the reader in the depicted action, its cinematic qualities as well as the manga-style sound words ("KRAK," "SPLATT") mark its indebtedness to the conventions of popular storytelling.

The next two pages are even more explicit in their remediation of cinematic strategies (Figure 8). Switching from close-ups of Lewis's battered face and head as he is losing consciousness to an unframed subjective shot that shows 


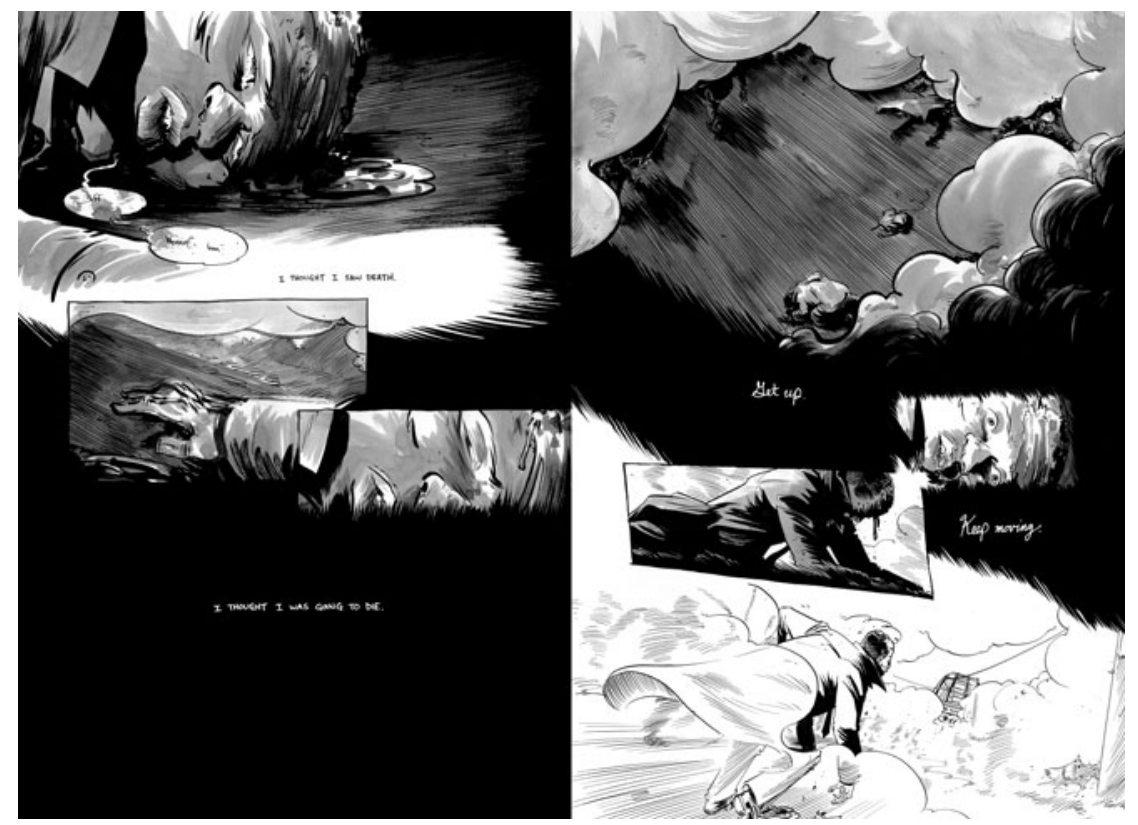

Figure 8. March (C) John Lewis and Andrew Aydin, courtesy Top Shelf Productions/IDW Publishing.

complete darkness except for the words "I thought I was going to die" in white letters, the narration offers a moment of internal focalization, where we become privy to Lewis's (recollected) thoughts. ${ }^{108}$ The opposite page zooms out again, supplanting the blackout scene with a high-angle shot of Lewis slowly coming to his senses, and then zooming back in again. "Get up. Keep moving," read the words accompanying these visuals, changing the narrative situation from the first-person narrator's retrospective "I thought I was going was going to die" in block letters to character speech in cursive. ${ }^{109}$ Paying attention to these details matters, since they shape our interpretation of the history constructed by the narrative as well as its emotional impact. Employing more or less subtle means of telling the story of the civil rights movement and of (re-)memorializing already heavily mediatized events for new audiences in a new medium, the March books definitely reward such a closer look.

\section{POLITICAL FAILINGS AND HISTORICAL FETISHES}

By advocating attention to its mediation and remediation of history and identifying the framing mechanisms at work in March, I do not mean to absolve 
this graphic memoir from its "political failings and historical fetishes." In fact, I would argue that these failings and fetishes are instructive in their own right and can serve as teachable moments. I have already mentioned the books' partial reiteration of the movement's master narrative as reason for critique, but I want to close with brief analyses of selected splash pages in Book Two that further trouble overly enthusiastic readings of the work. The first of these pages shows a bus carrying a group of black prisoners to the Mississippi State Penitentiary, also known as "Parchman Farm" (Figure 9). The prison is described as " $2 \mathrm{I}, 000$ acres of bullwhip-wielding guards and human bondage," and the accompanying image recalls photographs of Nazi concentration camps, suggesting at least a tenuous connection between the Holocaust and the suffering of African Americans in the Deep South, represented by guards that greet the freedom riders from a watchtower with their rifles drawn, a massive fence topped with barbed wire, and a sign over the entrance gate stating "Mississippi State Penitentiary" (versus Auschwitz's "Arbeit macht frei"). ${ }^{11}$ I On the immediately preceding page to the left, the prisoner's clothes, called "ring-arounds" and documented in many historical photographs, ${ }^{112}$ recall the uniforms of concentration camp inmates. Taken together, these visual references to the Holocaust and the depiction of the freedom riders' initiation into the prison - they are ordered to undress, forced to shave, and then compelled to put on prison clothes, with the narrator calling the whole process "dehumanizing" and "part of an effort to strip away our dignity" ${ }^{13}$ - establish a simultaneously powerful and potentially fraught analogy between the century-long oppression of African Americans and the genocide of the European Jews.

The analogy is powerful because it embeds the depiction of the civil rights movement in a longer history of systemic unfreedom, from the slaves' bondage to the Holocaust to Parchman's status as "the quintessential penal farm, the closest thing to slavery that survived the Civil War," and an embodiment of a "powerful link to the past-a place of racial discipline where blacks in striped clothing worked the cotton fields for the enrichment of others." ${ }^{114}$ In addition, by stating that "Parchman was the stuff of legends-dark legends," "Is Lewis and his collaborators conjure up the prison's symbolic significance as a testament to what David M. Oshinsky describes as "the ordeal of Jim Crow justice" in the subtitle of his study on the subject. In terms of

${ }_{110}$ Chaney, "Misreading with the President," 25.

${ }^{11}$ Lewis, Aydin and Powell, March: Book Two, 99.

${ }^{112}$ David M. Oshinsky, "Worse than Slavery": Parchman Farm and the Ordeal of Jim Crow Justice (New York: Free Press, 1997), I 37.

${ }_{113}$ Lewis, Aydin and Powell, March: Book Two, 102.

is Lewis, Aydin and Powell, March: Book Two, 99. 


\section{Daniel Stein}



Figure 9. March (C) John Lewis and Andrew Aydin, courtesy Top Shelf Productions/IDW Publishing. 
teaching methodology, the visual evocation of the Holocaust could be used as a prompt to discuss the March books alongside Art Spiegelman's seminal MAUS and other Holocaust comics, while the imprisoned freedom riders' singing could prepare the ground for exploring Parchman's appearance in classic blues songs by Son House, Leadbelly, and Bukka White. ${ }^{116}$

Yet the analogy between Jim Crow and the Holocaust, Parchman and Auschwitz, as subtle as it may be, is also fraught because it threatens to obscure the historical specificities of each event and might manipulate the reader's emotions by tapping into a transhistorical and transnational image archive - watchtowers, armed guards, fences and barbed wire, prison gates, dehumanized inmates. But then again, thirty-one prisoners, twenty-three of them black, were sent to the gas chamber at Parchman between 1954, the year of Brown v. Board of Education of Topeka, and 1964 , when the nationwide moratorium on capital punishment began. ${ }^{117}$ Perhaps the analogy between the Jim Crow prison and Nazi concentration camps is less far-fetched than it may seem at first glance, reminding readers, as Ta-Nehisi Coates claims for African Americans, that you "cannot disconnect our emancipation ... from Jim Crow from the genocides of the Second World War." ${ }_{118}$ Nonetheless, this scene and the many other jail scenes that place movement activists behind bars are never connected with the sprawling prison-industrial complex and today's mass incarceration of American Americans, which creates a certain disconnect with present concerns. ${ }^{19}$ Delving into these difficult issues could encourage students to think not just beyond the southern focus of civil rights memorialization but also beyond its preoccupation with national American history.

At an earlier point in the narrative, a white segregationist throws a stone through a stained-glass window of the 16 th Street First Baptist Church in Montgomery. It leaves a hole that obliterates Jesus Christ's head and thus symbolically categorizes the segregationist mob as un-Christian and the black activists as good Christians (recalling the framing of the Narrative of the Life of Frederick Douglass, An American Slave, Written by Himself). ${ }^{120}$ This somewhat heavy-handed symbolism takes on a more suggestive dimension in the very last

${ }^{116}$ Art Spiegelman, The Complete MAUS (New York: Pantheon, 1996); Neal Adams, Rafael Medoff, and Craig Yoe, eds., We Spoke Out: Comic Books and the Holocaust (San Diego: IDW, 2018).

${ }_{117}$ Oshinsky, 229.

${ }_{11} 8$ Ta-Nehisi Coates, Between the World and Me (New York: Spiegel \& Grau, 201 5), 96-97.

II Murakawa begins her book on the civil rights movement and the prison-industrial complex with a provocative statement: "One black man in the White House, one million black men in the Big House." Naomi Murakawa, The First Civil Right: How Liberals Built Prison America (Oxford: Oxford University Press, 2014), I.

${ }^{120}$ Lewis, Aydin and Powell, March: Book Two, 87; Frederick Douglass, Narrative of the Life of Frederick Douglass, An American Slave, Written by Himself, ed. William L. Andrews and William S. McFeely (New York: Norton, 1997). 


\section{Daniel Stein}

scene of Book Two. The scene depicts, in a rather cryptic fashion that presupposes a reader who is either aware of civil rights history or willing to research the missing context, the bombing of First Baptist Church in 1963 by members of the local Ku Klux Klan organization that killed Addie Mae Collins, Cynthia Wesley, Carole Robertson, and Carol Denise McNair. This four-page sequence moves from Obama's inauguration speech to a man in a phone booth (connected by the notion of "sacrifices borne by our ancestors" in the speech balloon that crosses the pages), to the actual bombing and its aftermath. ${ }^{\mathrm{I} I}$ Here, Jesus' missing face occurs again, but this time his heart has been crushed by the blast. The message is certainly sentimental, but it is also powerful because the not-so-subtle symbolism of the stained-glass window is accompanied by the smoke from the explosion, the sirens of police cars and ambulances, and two words in a brittle speech balloon: "Denise? Addie?" 122 Completing the act of closure, we are forced to come to terms with the fact that there can be no satisfying response to these words and that all we can do is develop our own response and formulate our own answers to this call for compassion - both as teachers and as students of the civil rights movement and its contested legacies.

\section{AUTHOR BIOGRAPHY}

Daniel Stein is Professor of North American Literary and Cultural Studies and Vice Dean for International Affairs, Faculty of Arts and Humanities, University of Siegen (Germany). He is the author of Music Is My Life: Louis Armstrong, Autobiography, and American Jazz (201 2) and coeditor, most recently, of Nineteenth-Century Serial Narrative in Transnational Perspective, I8305-1860s (2019). His work has appeared in the Southern Literary Journal, Popular Music and Society, the Journal of Graphic Novels and Comics, Genre, the European Journal of American Studies, and Amerikastudien/American Studies. He is coeditor of Anglia: Journal of English Philology and of the Anglia book series (De Gruyter), as well as a 2013 recipient of the Heinz Maier-Leibnitz Prize for outstanding scholarly achievements (German Research Foundations and Ministry of Education and Research). He is currently finishing a monograph tentatively titled Authorizing Superhero Comics: On the Evolution of a Popular Serial Genre (under contract with the Ohio State University Press).

${ }^{121}$ Ibid., $176-79$.

122 Ibid., 179 . 